\title{
Predator-induced changes of bacterial size- structure and productivity studied on an experimental microbial community
}

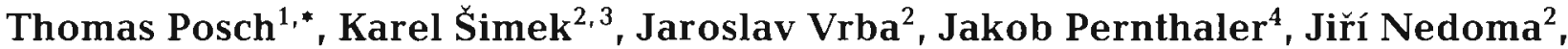 \\ Birgit Sattler ${ }^{1}$, Bettina Sonntag $^{1}$, Roland Psenner ${ }^{1}$
}

${ }^{1}$ Institute for Zoology and Limnology, University of Innsbruck, Technikerstr. 25, A-6020 Innsbruck, Austria

${ }^{2}$ Hydrobiological Institute of the Czech Academy of Sciences and ${ }^{3}$ Faculty of Biological Sciences, University of South Bohemia, Na sádkách 7, CZ-370 05 České Budějovice, Czech Republic

${ }^{4}$ Max Planck Institute for Marine Microbiology, Celsiusstrasse 1, D-28359 Bremen, Germany

\begin{abstract}
The grazing impact of 3 different protozoan species on a mixed bacterial community was studied by means of a simplified and functionally reproducible experimental microbial food web in a 2 stage flow-through system. In the first stage the algae Rhodomonas sp. was grown on an inorganic medium with its accompanying bacterial community (BC) growing on algal exudates. This mixture of algae and bacteria was transferred into 4 second stage vessels: (1) a control, and 3 vessels inoculated with (2) a heterotrophic nanoflagellate, Bodo saltans, (3) a scuticociliate, Cyclidium glaucoma, and (4) a mixotrophic flagellate, Ochromonas sp. Using image analysis techniques we followed the changes in bacterial size distributions and bacterial to protozoan total biovolume ratios over an experimental period of $15 \mathrm{~d}$. In addition, productivity of the grazed and ungrazed $\mathrm{BC}$ was measured using $\left[{ }^{3} \mathrm{H}\right]$ thymidine and $\left[{ }^{14} \mathrm{C}\right]$ leucine. As a consequence of total grazing rates and size-selective feeding we observed 3 different responses of the initially identical BC to grazing of the 3 protists. (1) Low grazing by $B$. saltans caused a slow decrease of bacterial cell numbers from 14 to $5.9 \times 10^{6} \mathrm{cells}^{-1}$, but no significant shift of the mean cell volume (MCV, average $0.107 \mu \mathrm{m}^{3}$ ) and bacterial production. (2) Higher grazing rates of C. glaucoma resulted in the decline of bacterial abundance to $3.3 \times 10^{6} \mathrm{cells}^{-1}$ in parallel with a doubling of the MCV to $0.207 \mu \mathrm{m}^{3}$ and high DNA and protein synthesis rates. Due to the ciliate's ability to graze also on small prey $(<1.5 \mu \mathrm{m})$ an increase in $\mathrm{MCV}$ seemed to provide higher grazing resistance or at least decreased vulnerability. (3) Ochromonas sp. showed the highest grazing rates and reduced bacterial numbers by 20 times within $2 \mathrm{~d}$. Only the smallest - obviously more grazing-protected - bacteria $(<0.9 \mu \mathrm{m})$ survived, which increased thereafter to almost initial bacterial densities. Although the bacterial MCV dropped to $0.038 \mathrm{\mu m}^{3},\left[{ }^{3} \mathrm{H}\right]$ thymidine uptake rates per cell were greatly enhanced and highly variable. Our results reflect the potential of $\mathrm{BC}$ responses to different predation regimes and the advantages of phenotypic traits in order to coexist with various grazers. This should be seen in the context of influencing bottom-up effects and the varying potential of individual bacterial species to change morphology, growth strategies, and activity patterns.
\end{abstract}

KEY WORDS: Continuous flow systems - Grazing resistance - Bacterial growth and size-structure Image analysis - Bodo saltans · Cyclidium glaucoma - Ochromonas $\mathrm{sp}$

\section{INTRODUCTION}

Heterotrophic nanoflagellates, mixotrophic flagellates, and small ciliates are known as the major con-

•E-mail: thomas.posch@uibk.ac.at sumers of heterotrophic bacterioplankton in freshwaters (Porter 1988, Berninger et al. 1991, Riemann et al. 1995, Simek et al. 1995). Consequently, protozoan feeding is thought to have a strong impact (Güde 1989) on the taxonomic diversity, apparent morphotypes and secondary production patterns of bacterial 
communities $(\mathrm{BC})$. The interactions of protozoa and bacteria perhaps represent the oldest predator-prey relationships we may study in nature (Jürgens \& Güde 1994), representing thus highly complex and multiple strategies of bacteria as a reaction to grazing and of protists to overcome such strategies (coevolution).

The introduction of more sophisticated methods to analyze parameters at the single bacterial cell level (Zimmermann et al. 1978, Sieracki et al. 1985, Šimek \& Fuksa 1989, Hicks et al. 1992) allowed more precise descriptions of the bacterial strategies to reduce grazing mortality or escape into resistance (Jürgens \& Güde 1994, and references therein). The most prominent and obvious effects are changes in the bacterial size distribution to inedible or less vulnerable morphologies (e.g. small cocci, filaments, prosthecate cells). These morphological shifts have been described in both field and laboratory experiments. They can be related to changes in taxonomic composition (Güde 1979, Pernthaler et al. 1997a, Simek et al. 1997) as well as to phenotypic plasticity of individual species (Shikano et al. 1990, Hahn \& Höfle 1998), and to the activity patterns of the whole BC (Bird \& Kalff 1993, Gasol et al. 1995).

Although laboratory experiments modeling these interactions always represent a simplification of the more complex relationships occurring in a natural system, they allow a detailed analysis of individual mechanisms that might otherwise be obscured by the simultaneous acting of various top-down and bottomup effects (Psenner \& Sommaruga 1992). However, a comprehensive comparison of published data on phenotypic responses of bacterial cells to grazing is strongly limited by the wide range of experimental conditions applied: different protozoan predators have been fed, e.g. with single bacterial species, very large bacteria or mixed $\mathrm{BC}$ of unknown taxonomy and/or activity status.

Therefore we set up a continuous flow system to establish a simplified, but functionally reproducible microbial food web based on a single algal species, its accompanying $\mathrm{BC}$ which mainly depended on exudates of the growing algae (Śimek et al. 1997, Vrba et al. unpubl.) and 3 different protozoan predators (Bodo saltans, Cyclidium glaucoma and Ochromonas sp.). We investigated the potential shifts in the $\mathrm{BC}$ considering the bacterial size distribution, activity and taxonomic composition (Pernthaler et al. unpubl.) as a consequence of grazing pressure, size-selective feeding, and growth strategies of protozoa. Image analysis was used for a detailed investigation of cell morphologies and biomasses of both predators and prey. Moreover bacterial activity as well as mortality rates of the microbial assemblages were determined.

\section{MATERIALS AND METHODS}

Design of the continuous flow system. Two large glass bottles (5 1 and 101$)$ were connected to store a sufficient volume of the inorganic WC (MBL) medium (Guillard \& Lorenzen 1972). The phosphorus content of the medium was reduced to $200 \mathrm{\mu g} \mathrm{P} \mathrm{l}^{-1}$. For the first stage of the system a vessel with a filling volume of 2.31 was used and aerated from the bottom (for details see Fig. 1). On top of the glass vessel were 5 openings--for de-aeration, for the medium inflow, for inoculation and sampling, and 2 for the connecting lines to the second stages. Special pear-shaped bacterial traps were used to disrupt the flows and to avoid a possible upstream migration of organisms. The second stage vessels with a filling volume of $750 \mathrm{ml}$ were also aerated from the bottom and had a lateral outflow (Fig. 1). We used 31 Erlenmeyer bottles sealed with rubber stoppers and sterile de-aeration for the outflow of medium. Silicon tubes with an inner diameter of 2 to $5 \mathrm{~mm}$ were utilized for the connections. Longer connections were divided into several smaller lines allowing a fast change of possibly damaged parts without changing the whole line. Two peristaltic pumps (Digital Drive MCP with cartridge pump heads, Ismatec, Switzerland) were applied for the transportation of the medium. We used pumping tubes with inner diameters of $1.02 \mathrm{~mm}$ and $2.06 \mathrm{~mm}$ (Ismatec, Switzerland) which have a long lifetime even in $24 \mathrm{~h}$ use and allowed an exact calibration of the peristaltic pumps (down to low flow-rates of $270 \mu \mathrm{l} \mathrm{min}{ }^{-1}$ ).

Set-up of the system. All parts were cleaned with distilled water and sterilized before the system was assembled in a walk-in chamber at $18 \pm 1^{\circ} \mathrm{C}$. The WC medium was pumped into the first and the second stages until all vessels were half-filled. Additionally, the aeration of all vessels was started. The first stage was inoculated with $50 \mathrm{ml}$ of a pure Rhodomonas sp. stock culture (strain 26.28 from the algal culture collection in Goettingen, Germany) with its accompanying bacteria. Pumping was stopped for $4 \mathrm{~d}$ until algae reached numbers of $10^{3} \mathrm{ml}^{-1}$ in the first stage. Thereafter, pumps were restarted again and algae were pumped into the second stage vessels. The dilution rate was set at $0.38 \mathrm{~d}^{-1}$ for the first stage and $0.25 \mathrm{~d}^{-1}$ for the second stages. When the abundance of Rhodomonas sp. was nearly equal in all stages we started sampling and considered this day as Day 0, still without addition of protozoa.

Three different protozoan species were inoculated into the second stages: a heterotrophic nanoflagellate (Bodo saltans), a mixotrophic flagellate (Ochromonas $\mathrm{sp}$.) and the scuticociliate Cyclidium glaucoma. All species were originally cultured in tap water on autoclaved wheat grains with the accompanying bacteria. 
Before the experiment, the protozoa were pre-cultivated in batch cultures of Rhodomonas sp. inoculated with protozoa that were washed free of bacteria by rinsing over $1 \mu \mathrm{m}$ filters (Simek et al. 1997). These protistan-Rhodomonas sp. stock cultures were held under continuous light at $18^{\circ} \mathrm{C}$. Twenty to $50 \mathrm{ml}$ of the cultures were used to inoculate the second stages at the end of Day 0.

Sampling and sample preparation. One hundred $\mathrm{ml}$ subsamples were collected from each vessel into pre-cleaned sterile $250 \mathrm{ml}$ Schott bottles every morning for a period of 2 wk. All subsamples were prefixed with Lugol's solution $0.5 \%$ final concentration $=$ f.c.) immediately followed by formaline ( $3 \%$ f.c.) and decolorized by several drops of sodium thiosulfate (3\%). Live subsamples were used for the determination of grazing via uptake rates of fluorescently labeled bacteria (FLB) (Sherr et al. 1987, Simek et al. 1994). The surrogates amounted to $<10 \%$ of the actual bacterial abundance and protists showed linear uptake rates within the first $20 \mathrm{~min}$ (data not shown). With regard to the optimal number of tracer particles per protozoan cell, hourly uptake rates (total grazing rates) were calculated from $5 \mathrm{~min}$ and $10 \mathrm{~min}$ feeding periods for ciliates and flagellates, respectively. Bacteria for the preparation of FLB were taken from the first stage of a previous experiment.

Bacterial numbers and cell dimensions were determined from 4',6-diamidino-2-phenylindole (DAPI, Sigma)

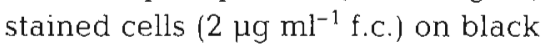
$0.2 \mu \mathrm{m}$ pore sized polycarbonate filters (Poretics, USA). Staining conditions and time (7 min) were kept constant during the experiment to obtain comparable signal intensity for counting and image processing. We used Zeiss Axioplan, Axiovert, and Axiophot 2 microscopes with optovars (up to $2.5 \times$ ) and $40 \times$ and $100 \times$ oil objectives. Bacterial abundances were always determined by the same person during the whole experiment to reduce counting error ( $-5 \%$, data not shown, cf. Kirchman et al. 1982). Between 500 and 700 cells were counted per sample at a magnification of $1250 \times$. Images ( $524 \times 752$ pixels, 8 -bit, pixel size: $0.065 \mu \mathrm{m})$ of stained cells were recorded at a magnification of $125 x$ with a highly sensitive CCD camera (Optronics ZVS$47 \mathrm{EC}$ ) and processed with the image analysis software LUCIA D (Version 3.52ab, Laboratory Imaging Prague, Czech Republic, http://www.lim.cz). At least 500 bac-

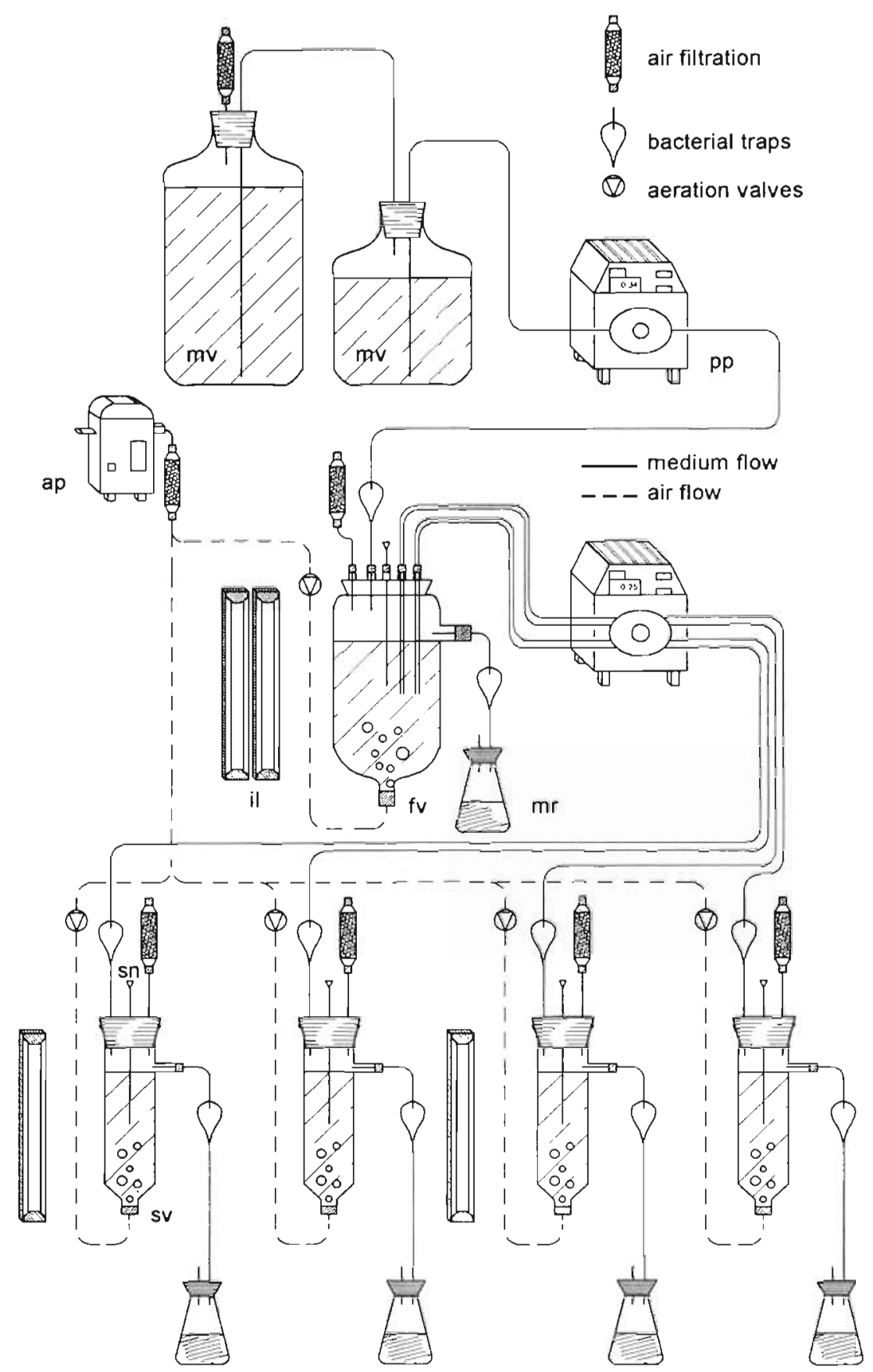

Fig. 1. Scheme of the 2-stage continuous flow system. (ap: aeration pump; fv: first stage vessel; il: illumination; mv: medium vessel; mr: medium fluid recipient; pp: peristaltic pump; sn: steel needle for sampling; sv: second stage vessel) 
teria were analyzed per sample and the most reliable parameters of pixel measurement were chosen: cell area and cell perimeter. We calculated cell dimensions (length, width, volume) according to algorithm 3 published by Massana et al. (1997). Details of the image processing (gray transformation, edge finding) are described in Pernthaler et al. (1997b) and Posch et al. (1997).

Algae and protozoa were filtered onto $1.0 \mu \mathrm{m}$ pore sized black polycarbonate filters (Poretics, USA), stained with DAPI $\left(0.5\right.$ to $1 \mu \mathrm{g} \mathrm{m}^{-1}$ f.c.) and counted at a magnification of $400 \times$. Cell dimensions were measured interactively with a computer mouse on the screen using the same image analysis software as described above. We measured lengths and widths of at least 100 protozoan cells per sample and calculated the cell volume using simple geometrical formulas like those for half ellipsoids or spheres. Bacterial and protozoan total biovolumes $\left(\mathrm{mm}^{3} \mathrm{l}^{-1}\right)$ were calculated from the observed abundances (cells ${ }^{-1}$ ) times the mean cell volume (MCV) $\left(\mathrm{\mu m}^{3} \mathrm{cell}^{-1}\right)$. To follow the development of all organisms in the experimental set-up all samples were analyzed on the same day as sampling.

Determination of bacterial production. The modified method of Simon (1990) was applied for a combined measurement of cell multiplication rates via $\left[{ }^{3} \mathrm{H}\right]$ thymidine incorporation (specific activity 70 to $90 \mathrm{Ci} \mathrm{mmol}^{-1}$, Amersham) and protein synthesis via $\left[{ }^{14} \mathrm{C}\right]$ leucine incorporation (specific activity $310 \mathrm{mCi}$ $\mathrm{mmol}^{-1}$ ). Five $\mathrm{ml}$ of triplicate samples were incubated with $\left[{ }^{3} \mathrm{H}\right]$ thymidine (5 nM f.C.) and $\left[{ }^{14} \mathrm{C}\right.$ lleucine $(20 \mathrm{nM}$ f.c.) for $60 \mathrm{~min}$ at $18^{\circ} \mathrm{C}$. After Day 2 the incubation time was reduced to $30 \mathrm{~min}$ because of increasing bacterial growth. Uptake of radiochemicals was stopped by the addition of $0.5 \mathrm{ml}$ formaline ( $4 \% \mathrm{f}$.c.). Blanks were pro-

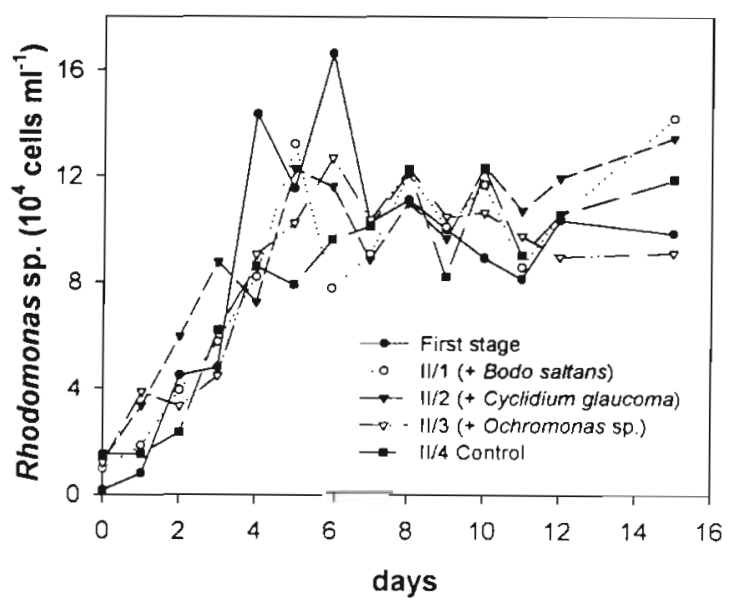

Fig. 2. Abundances of Rhodomonas sp. in the first stage, control and all other vessels of the second stage during the experimental period of $15 \mathrm{~d}$ duced by fixing the sample with formaline and adding the radiotracers after $15 \mathrm{~min}$ to correct for abiotic absorption of $\left[{ }^{3} \mathrm{H}\right]$ thymidine and $\left[{ }^{14} \mathrm{C}\right]$ leucine. Filters were rinsed twice with ice-cold trichloric acetic acid (TCA) and then with particle-free distilled water before samples were filtered onto white polycarbonate filters $(0.2 \mu \mathrm{m}$ pore size, Poretics). Five $\mathrm{ml}$ of TCA were used for disruption of cells and the extraction of macromolecules (DNA and proteins). After filtration the filters were washed again 3 times with TCA to remove all remaining cell fragments. Afterwards, filters were dried and $10 \mathrm{ml}$ of a scintillation cocktail (Beckman Ready Safe) were added. After 5 to 6 h, i.e. after complete disintegration of the filters, samples were counted twice for $10 \mathrm{~min}$, with internal quench correction (Beckman Liquid Scintillation Counter LS 6000 IC).

\section{RESULTS}

\section{Development of bacterial abundances and MCV}

During the first $5 \mathrm{~d}$ of the experiment Rhodomonas sp. increased from 2 to $8 \times 10^{4}$ cells ml ${ }^{-1}$, then stabilized at 8 to $12 \times 10^{4} \mathrm{cells} \mathrm{ml}^{-1}$, with slight fluctuations over the investigation period in all experimental vessels (Fig. 2). MCV of algae in all second stages except with Ochromonas sp. lay in the range of 273 to $288 \mathrm{\mu m}^{3}$ during the $15 \mathrm{~d}$. In that vessel Rhodomonas sp. cells showed a higher mean volume of $338 \mu \mathrm{m}^{3}$.

(1) Bacterial abundance in the first stage increased slowly during the $15 \mathrm{~d}$, likely associated with rising algal numbers reaching mean values of $8.5 \times 10^{6}$ cells $\mathrm{ml}^{-1}$ (Fig. 3). These bacterial cells had a very constant $\mathrm{MCV}$ of $0.110 \pm 0.015 \mu \mathrm{m}^{3}$ (mean $\pm \mathrm{SD}$ ), mostly rodshaped with mean cell dimensions of $1.25 \times 0.36 \mu \mathrm{m}$.

(2) The addition of Bodo saltans in one of the second stages resulted in an unexpected slow development of protozoan numbers instead of logarithmic growth, especially during the first days of the experiment. A maximum number of $1.8 \times 10^{4}$ cells ml ${ }^{-1}$ and a total grazing rate of $2.2 \times 10^{5} \mathrm{cells} \mathrm{ml}^{-1} \mathrm{~h}^{-1}$ was reached at the last day (Fig. 3). During the experiment a mean individual grazing rate of $13.8 \pm 3.6$ bacteria $^{-1}$ flagellate $^{-1}$ was observed. Although we still do not know the reasons for the slow protozoan growth, we decided to include this data set as an example of lower grazing in comparison to the 2 other protistan-influenced variants. Bacterial abundance in this vessel decreased from 14.0 to $5.9 \times 10^{6} \mathrm{cells} \mathrm{ml}^{-1}$ whereas the MCV fluctuated around $0.107 \pm 0.016 \mathrm{\mu m}^{3}$ during the test period. At the end of the experiment, bacteria had increased in numbers with a slight trend towards smaller cells (MCV at Day 15: $0.091 \mathrm{\mu m}^{3}$ ). 
(3) The inoculation of Cyclidium glaucoma caused a bacterial decrease to $3.3 \times 10^{6}$ cells $\mathrm{ml}^{-1}$ (Fig. 3 ). Ciliates showed fast exponential growth and reached up to 2000 cells $\mathrm{ml}^{-1}$. A mean individual grazing rate of $548 \pm 172$ bacteria $\mathrm{h}^{-1}$ ciliate $^{-1}$ was measured. The total grazing rate increased until Day 6 to a maximum of $5.8 \times 10^{5}$ cells $\mathrm{ml}^{-1} \mathrm{~h}^{-1}$ and the grazing pressure caused an obvious shift in bacterial cell dimensions. The MCV nearly doubled to $0.207 \mu^{3}$ (mean volume during the experiment: $0.160 \pm 0.032 \mu \mathrm{m}^{3}$ ).

(4) The addition of Ochromonas sp. resulted in a 20 -fold decrease of bacterial numbers within $2 \mathrm{~d}$ (Fig. 3). Bacterial abundance dropped from 12.0 to $0.7 \times 10^{6}$ cells $\mathrm{ml}^{-1}$ with a simultaneous strong decrease in $\mathrm{MCV}$ to $0.038 \mathrm{\mu m}^{3}$. During the whole experiment a bacterial MCV of $0.059 \pm 0.023 \mu \mathrm{m}^{3}$ was calculated. Ochromonas sp. grew constantly until Day 15 and reached cell numbers of $8.2 \times 10^{4}$ cells $\mathrm{ml}^{-1}$. This protist showed the highest total grazing rates of the tested organisms resulting in a maximal value of $10.9 \times$ $10^{5}$ cells $\mathrm{ml}^{-1} \mathrm{~h}^{-1}$. We observed a mean individual grazing rate of $14.5 \pm 4.8$ bacteria $h^{-1}$ flagellate ${ }^{-1}$ for the whole experiment

(5) Bacterial abundances in the control, predator-free vessel of the second stage remained quite stable during the experiment, with slightly higher numbers (on average $1.2 \times 10^{7}$ cells $\left.\mathrm{ml}^{-1}\right)$ and $\mathrm{MCV}\left(0.130 \pm 0.015 \mathrm{\mu m}^{3}\right)$ than in the first stage (Fig. 3). This phenomenon was often observed during earlier experiments (Šimek et al. 1997), presumably caused by a slower dilution rate of $0.25 \mathrm{~d}^{-1}$ in comparison to $0.38 \mathrm{~d}^{-1}$ of the first stage which allowed bacteria to grow up and accumulate.

The bacterial MCV in the vessels with Ochromonas $\mathrm{sp}$. and Cyclidium glaucoma were significantly different from each other and all other stages (ANOVA, Scheffé post hoc comparison, $p<0.05)$. However we found no significant differences between the bacterial MCV of the first stage, the vessel inoculated with Bodo saltans and the control (ANOVA, Scheffé post hoc comparison, $\mathrm{p}<0.05$ ).

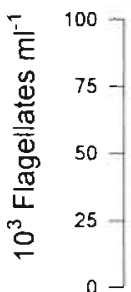

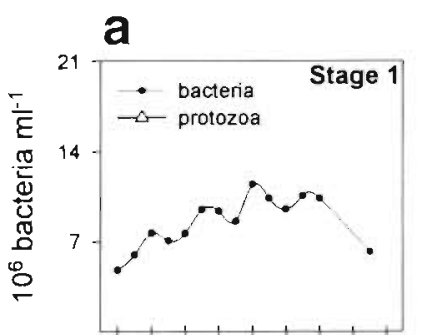

b
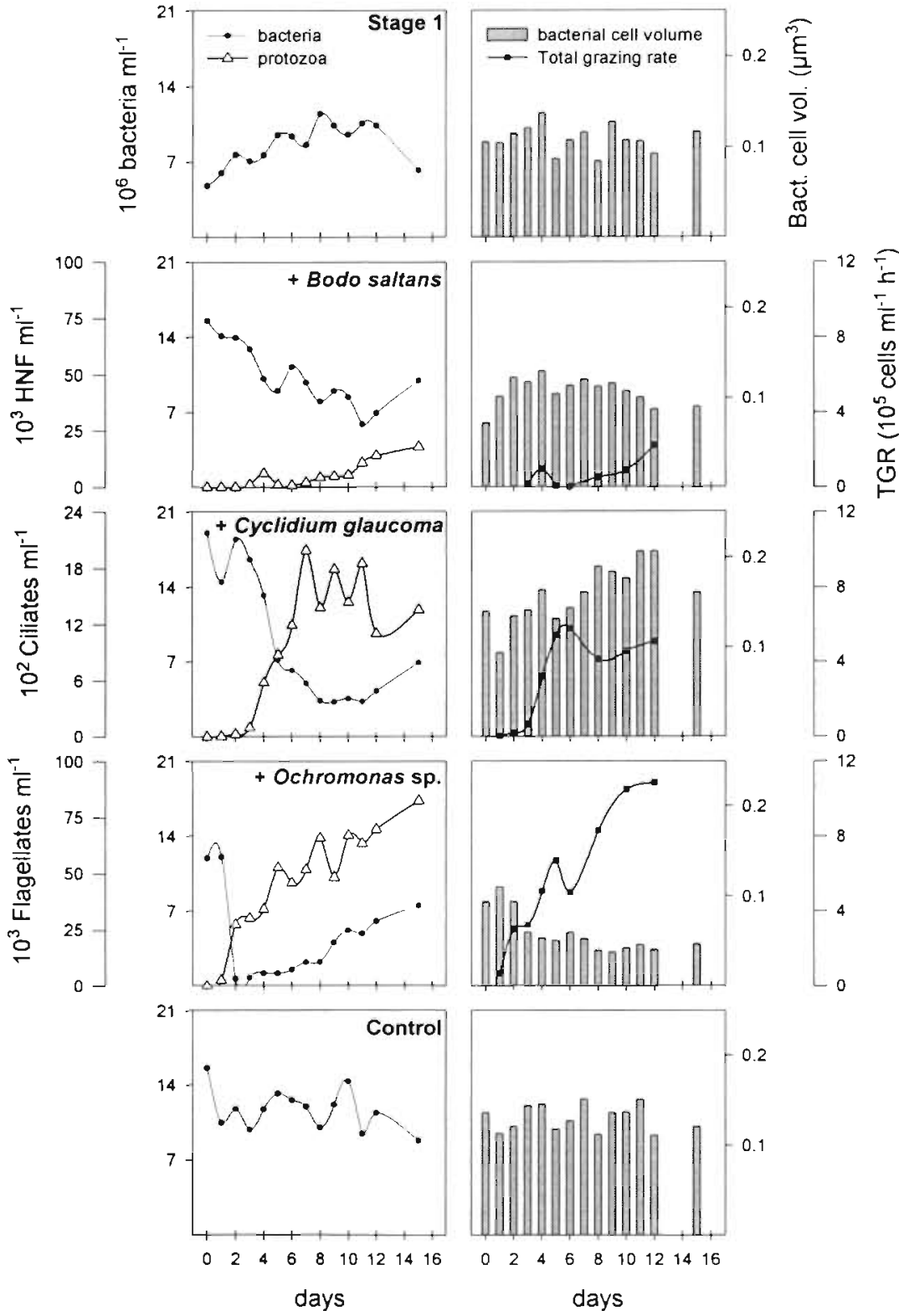

Fig. 3. (a) Changes in bacterial and protozoan cell numbers in the first stage and the 4 second stage vessels. (b) Development of bacterial cell volumes and total grazing rates after inoculation of Bodo saltans, Cyclidium glaucoma and Ochromonas sp.

\section{Development of bacterial size classes associated with grazing}

We split the image analysis data into 5 distinct size classes to differentiate selective feeding by the 3 protozoan species (Fig. 4). Cell lengths were chosen as decisive factors because cell widths remained quite stable during the experiment at all stages $(0.36 \pm 0.02$ $\mu \mathrm{m})$ except after addition of Ochromonas $\mathrm{sp} \cdot(0.28 \pm$ 

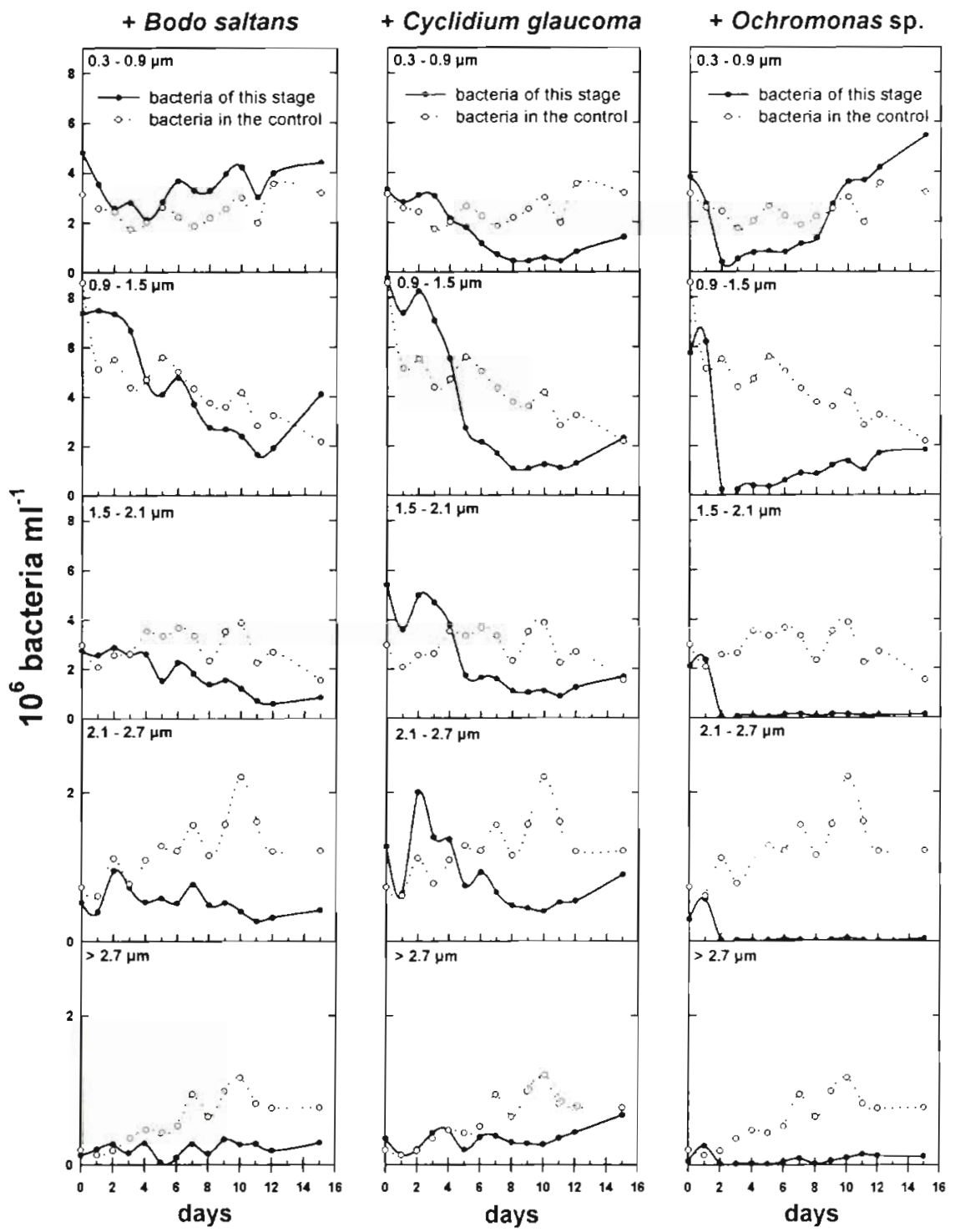

Fig. 4. Changes of the bacterial size class distributions after inoculation with 3 different protistan predators. The cell-size data were split into 5 size classes and the development of each class in the predator stages is compared with the control stage (predator-free)

$0.04 \mu \mathrm{m})$. This data treatment allowed a detailed description of bacterial size shifts, which are not obvious when only the $\mathrm{MCV}$ is considered (compare for instance Fig. 4 with Fig. 3). Abundances of smallest $(0.3$ to $0.9 \mu \mathrm{m})$ and medium-sized cells $(1.5$ to $2.1 \mu \mathrm{m})$ remained stable in the control stage over the observed period whereas the abundance of larger cells increased slightly with time. We do not know which smaller cells were growing up during the experiment and therefore contributed to larger size classes. The addition of Bodo saltans caused an increase of smaller bacteria and a moderate decrease of larger cells. The scuticociliate Cyclidium glaucoma reduced the abundance of all size classes within 0.3 to $2.7 \mu \mathrm{m}$ cell length but caused a slight increase of the larger cells $(>1.5 \mu \mathrm{m})$ in contrast with the other 2 predator systems. Only C. glaucoma had a permanent negative effect on the abundance of the smallest bacteria. Ochromonas sp. eliminated nearly all cells larger than $1.5 \mu \mathrm{m}$, reducing numbers down to $10^{4}$ cells $\mathrm{ml}^{-1}$, but the smallest forms survived this strong grazing pressure and became dominant at the end of the experiment

\section{Cell-specific uptake rates of labeled thymidine and leucine}

Bacteria in the first stage showed constant uptake rates after $5 \mathrm{~d}$. At that time numbers and biovolumes of algae, the only substrate suppliers for bacteria, reached their maxima, then kept similar values throughout the experiment (Fig. 2). We observed only slight fluctuations of $\left[{ }^{14} \mathrm{C}\right]$ leucine uptake in the control vessel whereas the uptake of $\left[{ }^{3} \mathrm{H}\right]$ thymidine nearly 


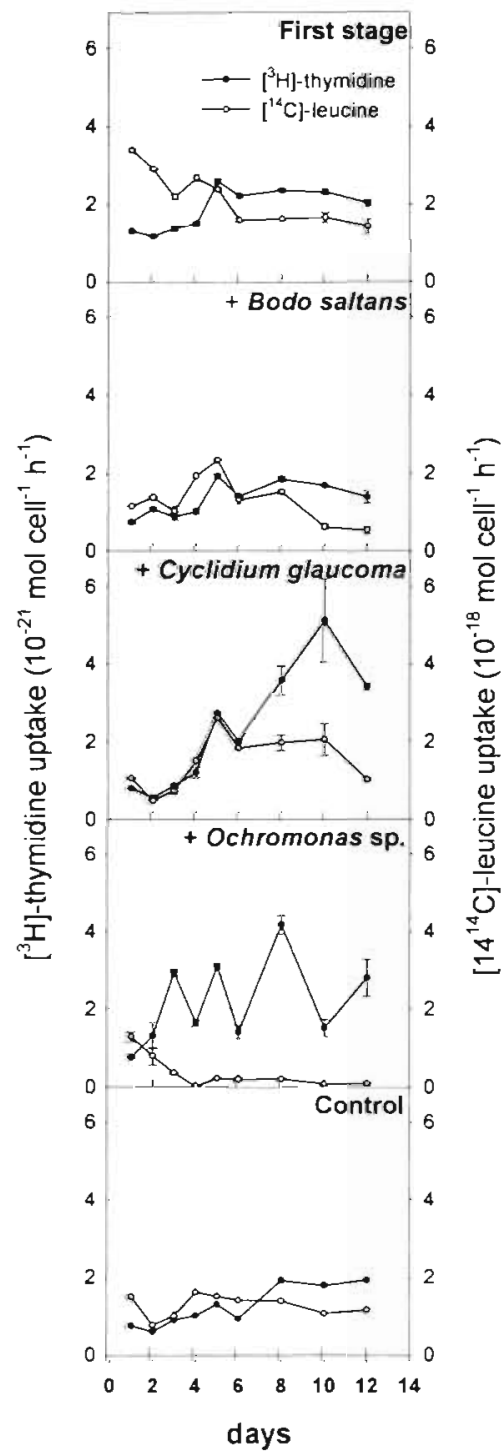

Fig. 5. Cell-specific uptake rates of $\left[{ }^{3} \mathrm{H}\right]$ thymidine and $\left[{ }^{14} \mathrm{C}\right]$ leucine in the first stage, after addition of protozoan predators, and in the control stage

doubled with time (Fig. 5). Bacterial production in the first stage and the control showed nearly equal patterns after Day 8.

Protozoan grazing led to tremendous changes of secondary production, resulting in 2 contrasting bacterial responses. After addition of Cyclidium glaucoma, uptake rates of $\left[{ }^{3} \mathrm{H}\right]$ thymidine and $\left[{ }^{14} \mathrm{C}\right]$ leucine increased in parallel until Day 5. Specific uptake of $\left.{ }^{3} \mathrm{H}\right]$ thymidine increased furthermore up to $5.1 \times 10^{-21} \mathrm{~mol} \mathrm{cell}^{-1}$ $\mathrm{h}^{-1}$. Bacteria showed the highest leucine uptake rates of all second stage vessels (up to $2.6 \times 10^{-18} \mathrm{~mol} \mathrm{cell}^{-1}$ $\mathrm{h}^{-1}$ ), which suggests that bacteria reacted on grazing pressure by replicating faster and growing larger (Figs. $3 \& 4$ ).
On the other hand, immediately after inoculation of Ochromonas sp. bacterial thymidine uptake rates increased extremely fast whereas the uptake of leucine dropped to very low values (Fig. 5). While DNA synthesis rates showed strong and regular fluctuations after Day 3 , leucine uptake rates remained extremely low until the end of the experiment. The abundance of cells $<1.5 \mu \mathrm{m}$ increased constantly, parallel with rising uptake rates of $\left[{ }^{3} \mathrm{H}\right]$ thymidine (compare Figs. 4 \& 5). The low feeding activities of Bodo saltans caused no distinct production pattern in comparison to the control stage.

\section{Development of bacterial and protozoan total biovolumes}

The MCV of protists over the experiment were as follows: Bodo saltans $\left(43 \pm 12 \mu \mathrm{m}^{3}\right)$, Cyclidium glaucoma $\left(1264 \pm 324 \mu^{3}\right)$ and Ochromonas sp. $\left(120 \pm 51 \mu^{3}\right)$. Especially in the phase of intensive protistan growth we observed higher variations of the MCV mainly caused by high percentages of dividing cells. Although $B$. saltans developed very slowly during the experiment, it caused a slight decrease of total bacterial biovolume. Due to high total grazing rates of C. glaucoma, bacterial biovolume dropped to $0.60 \mathrm{~mm}^{3} \mathrm{l}^{-1}$. An increase in the MCV (see Fig. 3) compensated this effect and the proportion of bacterial to protozoan total biovolume moved to a 1:1 ratio (Fig. 6). The addition of Ochromonas sp., which developed the highest biovolumes of the 3 tested organisms (up to $16 \mathrm{~mm}^{3} \mathrm{l}^{-1}$ ), caused a reduction of bacterial biovolume down to $0.05 \mathrm{~mm}^{3} \mathrm{l}^{-1}$. The ratio of protistan versus bacterial biovolume reached on some days up to $7000 \%$ (Fig. 6). As a consequence of the steep increase in numbers of the smallest size class (see Fig. 4) bacterial biovolumes increased at the end of the experiment.

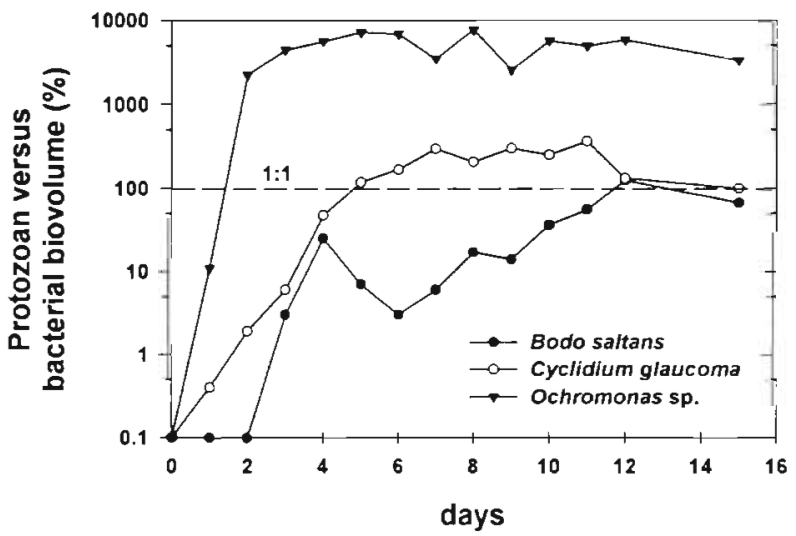

Fig. 6. Time course of protozoan versus bacterial total biovolume $(\%)$ during the experiment. Note the logarithmic scale to present the high biovolume ratios of Ochromonas sp. 


\section{DISCUSSION}

Although we worked with a simplified experimental microbial food web, we could observe relatively high phenotypic and genotypic plasticity of the microbial community reflected in bacterial size distributions (Fig, 4) and the contrasting patterns of production (Fig. 5).

The initially identical bacterial composition in the second stage vessels, as revealed by oligonucleotide probing (Pernthaler et al. unpubl.), developed 3 distinct 'responses' to grazing pressure. Low grazing by Bodo saltans only caused a decline of bacterial numbers and the total grazing rate per hour (TGR) never exceeded $3 \%$ of the actual bacterial standing stock (average: $0.9 \%$ ). However, bacterial numbers decreased while the mean cell size did not, and DNA and protein synthesis rates did not show patterns different from those observed in the control vessel. All presented total grazing rates in this study were determined by uptake rates of FLB. We know that this method has some real drawbacks as we had to use the same surrogates during the whole experiment independent of the observed size shifts in the $\mathrm{BC}$.

Grazing by Cyclidium glaucoma increased until Day 6 and the TGR reached $12 \%$ of bacterial standing stock hourly removed (average: $6.3 \%$ ). The $\mathrm{BC}$ reacted by doubling of the mean cell size as reflected by higher abundances of cells $>1.5 \mu \mathrm{m}$, which did not happen in the other 2 predator-exposed variants. Due to increasing bacterial cell sizes during the $14 \mathrm{~d}$, the initial decrease of total bacterial biovolume was compensated over time and nearly reached the predator's biovolume. According to the literature, this scuticociliate can also ingest smaller prey, even particles down to a diameter of $0.2 \mu \mathrm{m}$ (Fenchel 1980a). In our study $C$. glaucoma was the only predator able to reduce the smallest size class of 0.3 to $0.9 \mu \mathrm{m}$ throughout the experiment. However, it is difficult to define the optimal prey size range for this scuticociliate (Table 1). Simek et al. (1994) reported highest ingestion rates (up to 24 bacteria ciliate ${ }^{-1} \mathrm{~min}^{-1}$ ) for a single bacterial species with a volume of $0.377 \mu \mathrm{m}^{3}$ whereas maximal clearance rates for latex beads of $0.36 \mu \mathrm{m}$ diameter $\left(\sim 0.024 \mu^{3}\right)^{3}$ were described by Fenchel (1980a). Grazing activities of $C$. glaucoma had a strong impact on the cell-specific DNA and protein synthesis rates, which hints at how close top-down and bottom-up effects may be interrelated. Size-selective feeding by this ciliate caused a shift to larger, less vulnerable morphotypes with higher division rates (top-down effect), and since this $B C$ was not apparently limited by substrates, it could react on grazing pressure by increasing the cell-specific activity (bottom-up effect).

The mixotrophic flagellate Ochromonas sp. grew to a total biovolume 20 -fold larger than the bacterial standing stock, obviously profiting from $24 \mathrm{~h}$ illumination (and potentially from residual nutrients of the inor-

Table 1. Ingestion rates of Cyclidium sp. for different-sized prey particles. FLB: fluorescently labeled bacteria

\begin{tabular}{|c|c|c|c|c|c|c|}
\hline $\begin{array}{l}\text { Particle } \\
\text { volume } \\
\left(\mu \mathrm{m}^{3}\right)\end{array}$ & Particle type & $\begin{array}{l}\text { Particle } \\
\text { morphology } \\
(\mu \mathrm{m})\end{array}$ & $\begin{array}{l}\text { Particle } \\
\text { concentration } \\
\text { (cells } \mathrm{ml}^{-1} \text { ) }\end{array}$ & $\begin{array}{l}\text { Ingestion } \\
\text { (particles } \\
\text { ciliate } \mathrm{min}^{-1} \text { ) }\end{array}$ & $\begin{array}{l}\text { Preferred } \\
\text { size }\left(\mu \mathrm{m}^{3}\right)\end{array}$ & Source \\
\hline 0.007 & Latex beads & 0.23 spherical & $0.2-58 \times 10^{9}$ & $2.6-7.8$ & & Fenchel (1980a) \\
\hline 0.024 & Latex beads & 0.36 spherical & $4.0-96 \times 10^{4}$ & $7.0-216.2$ & & Fenchel (1980a) \\
\hline 0.065 & Bacterioplankton + FLB & Cocci + rods & $0.3-11 \times 10^{6}$ & $0.6-10.6$ & $0.082-0.096$ & Sirnek et al. (1994) \\
\hline 0.106 & Bacterioplankton + FLB & Cocci + rods & $0.5-1.4 \times 10^{6}$ & $2.3-8.8$ & $0.105-0.111$ & Simek et al. (1994) \\
\hline 0.113 & $\begin{array}{l}\text { Carboxylated fluorescent } \\
\text { microspheres }\end{array}$ & 0.60 spherical & $\begin{array}{l}0.5-4.8 \times 10^{6} \\
7.0-13.0 \times 10^{7}\end{array}$ & $\begin{array}{l}0.4-2.9 \\
40.7-93.9\end{array}$ & & Sanders (1988) \\
\hline 0.113 & $\begin{array}{l}\text { Protein treated } \\
\text { fluorescent microspheres }\end{array}$ & 0.60 spherical & $\begin{array}{l}0.6-59 \times 10^{6} \\
23-49 \times 10^{7}\end{array}$ & $\begin{array}{l}0.4-36.1 \\
139.3-134.5\end{array}$ & & Sanders (1988) \\
\hline 0.202 & Alcaligenes xylosoxidans & $0.97 \times 0.57$ rods & & 17.0 & 0.275 & Simek et al. (1994) \\
\hline 0.377 & Alcaligenes xylosoxidans & $1.43 \times 0.62$ rods & & 24.4 & 0.352 & Simek et al. (1994) \\
\hline 0.421 & $\begin{array}{l}\text { Carboxylated fluorescent } \\
\text { microspheres }\end{array}$ & 0.93 spherical & $\begin{array}{l}0.3-10 \times 10^{5} \\
10 \times 10^{7}\end{array}$ & $\begin{array}{l}0.03-2.6 \\
9.0\end{array}$ & & Sanders (1988) \\
\hline 0.421 & $\begin{array}{l}\text { Protein treated } \\
\text { fluorescent microspheres }\end{array}$ & 0.93 spherical & $\begin{array}{l}0.3-18 \times 10^{6} \\
13 \times 10^{7}\end{array}$ & $\begin{array}{l}0.07-6.2 \\
9.5\end{array}$ & & Sanders (1988) \\
\hline 0.678 & Latex beads & 1.09 spherical & $3-40 \times 10^{7}$ & $0.4-1$ & & Fenchel (1980a) \\
\hline
\end{tabular}


ganic WC medium). Although the numbers of the Rhodomonas sp. population in the second stages were continuously stabilized by influx from the first stage (Fig. 2), Ochromonas sp. could successfully establish a dense population in association with the autotroph. This can only be explained by the ability of the chrysophyte to acquire limiting nutrients by phagotrophy (Rothhaupt 1996). The total hourly grazing rates of Ochromonas sp. reached up to $50 \%$ of the bacterial standing stock (average 32\%). We could observe a prominent impact of total grazing on bacterial cell-specific activity (Fig. 5) and on the size distribution of the total BC. All bacterial size classes were reduced by nearly 2 orders of magnitude within 2 d after inoculation with Ochromonas sp, and bacteria $>0.9 \mu \mathrm{m}$ never recovered from grazing pressure. The smallest size class $(0.3$ to $0.9 \mu \mathrm{m}$ ) seemed to be less grazing-vulnerable and these bacteria, very uniform in shape, started to increase in number already after the second day as indicated by image analysis data and high uptake rates of $\left[{ }^{3} \mathrm{H}\right]$ thymidine. At the end of the experiment bacterial abundance (but not biomass) was similar to the original density on Day 0 . Bacteria thus reacted to grazing by high division rates compensating for high mortality, but not by an enlargement of their mean cell size, as indicated by low per cell protein synthesis rates. When we compare activity patterns of the protistan-influenced $\mathrm{BC}$ with the control stage we should consider feedback mechanisms of intensive grazing, e.g. remineralization of phosphorus or carbon. In our former experiments we could always observe an increase in Rhodomonas sp. biomasses as a consequence of intensive protistan grazing on bacteria (Vrba et al. unpubl.) and this phenomenon is also described by several authors (Caron et al. 1988, Rothhaupt 1992). On the other hand feeding on bacteria and simultaneous remineralization of nutrients could have a direct positive feedback on the bacterial prey itself. This effect would consequently not appear in our control vessel.

When comparing the effects of the 3 tested protists on the $\mathrm{BC}$, several important aspects of grazing must be considered, such as the total grazing rate, prey-size selection and how rapidly these parameters change over time (Fig. 7). The magnitude of total grazing and its increase over time is probably a decisive factor for how rapidly bacteria have to react to grazing induced mortality, and consequently which fraction of the bacterial standing stock with respect to species composition, numbers and cell sizes will be reduced.

Each protozoan species shows highest clearance rates for a distinct prey-size class (Fenchel 1980b), and for larger ciliates this range may even change with the size of the predator during its life cycle (Fenchel 1980a). However, we may assume a rather constant pattern of size selectivity of our small tested organisms during their cell cycles. There is increasing evidence that natural protozoan communities selectively feed on the larger-sized fraction of bacterioplankton (Andersson et al. 1986, Chrzanowski \& Šmek 1990, Gonzalez et al. 1990, Sherr et al. 1992, Bird \& Kalff 1993, Jürgens \& Güde 1994). Such a preference for distinct size classes would not only cause a general reduction of bacterial biomass but also an above-average loss of the active and dividing cells if they fall into the vulnerable size range. Protozoan grazing will therefore sometimes have a stronger impact on bacterial production (Gonzalez et al. 1990, Sherr et al. 1992) or the most active bacterial fraction (Gasol et al. 1995) than on total standing stock. However, bacteria within the edible size range may compensate loss rates by an increased cell division without conspicuous morphological changes (Fig. 7). This has been suggested for members of the alpha-Proteobacteria in a comparable experimental community (Pernthaler et al. 1997a). Alternatively, cells could also keep their original size if they are indigestible or even toxic for their predators.

Another possibility to escape grazing is a shift to inedible or less vulnerable size classes (Fig. 7). Some bacteria may be able to decrease in size and, consequently, reduce ingestion rates (Andersson et al. 1986). As the removal of large edible bacteria probably caused a shift in competition within the $\mathrm{BC}$ in the presence of Ochromonas sp., the initially minor fraction of small bacteria were therefore released from limitation by substrate or nutrients. They could thus enhance division rates (Fig. 5) and compensate for high mortalities. This can also be deduced from the initial reduction of abundances in this size class after the addition of Ochromonas sp. and the subsequently observed regrowth (Fig. 4). Bacteria coexisting with the mixotroph stabilized at an average cell size of $0.04 \mathrm{\mu m}^{3}$, which falls into the size range of the majority of bacteria in freshwater or marine planktonic systems (Billen et al. 1990). This observation raises the question of whether larger bacteria are indeed the only or predominant fraction of a planktonic community that may show high growth and division rates. Andersson et al. (1986) observed very similar effects of grazing activities by a marine Ochromonas sp. The offered BC decreased its $\mathrm{MCV}$ by $47 \%$ and the abundance of smaller cells $\left(<0.05\right.$ to $\left.0.1 \mu^{3}\right)$ increased during the experimental period of $14 \mathrm{~d}$.

A frequently discussed strategy of acquiring grazing resistance is the formation of filaments (Güde 1979, Shikano et al. 1990, Sommaruga \& Psenner 1995, Simek et al. 1997), cells with a complex morphology (e.g. prosthecate cells, Bianchi 1989) or aggregates (Jürgens \& Güde 1994). Threadlike bacteria are usually not important numerically yet in terms of biomass 

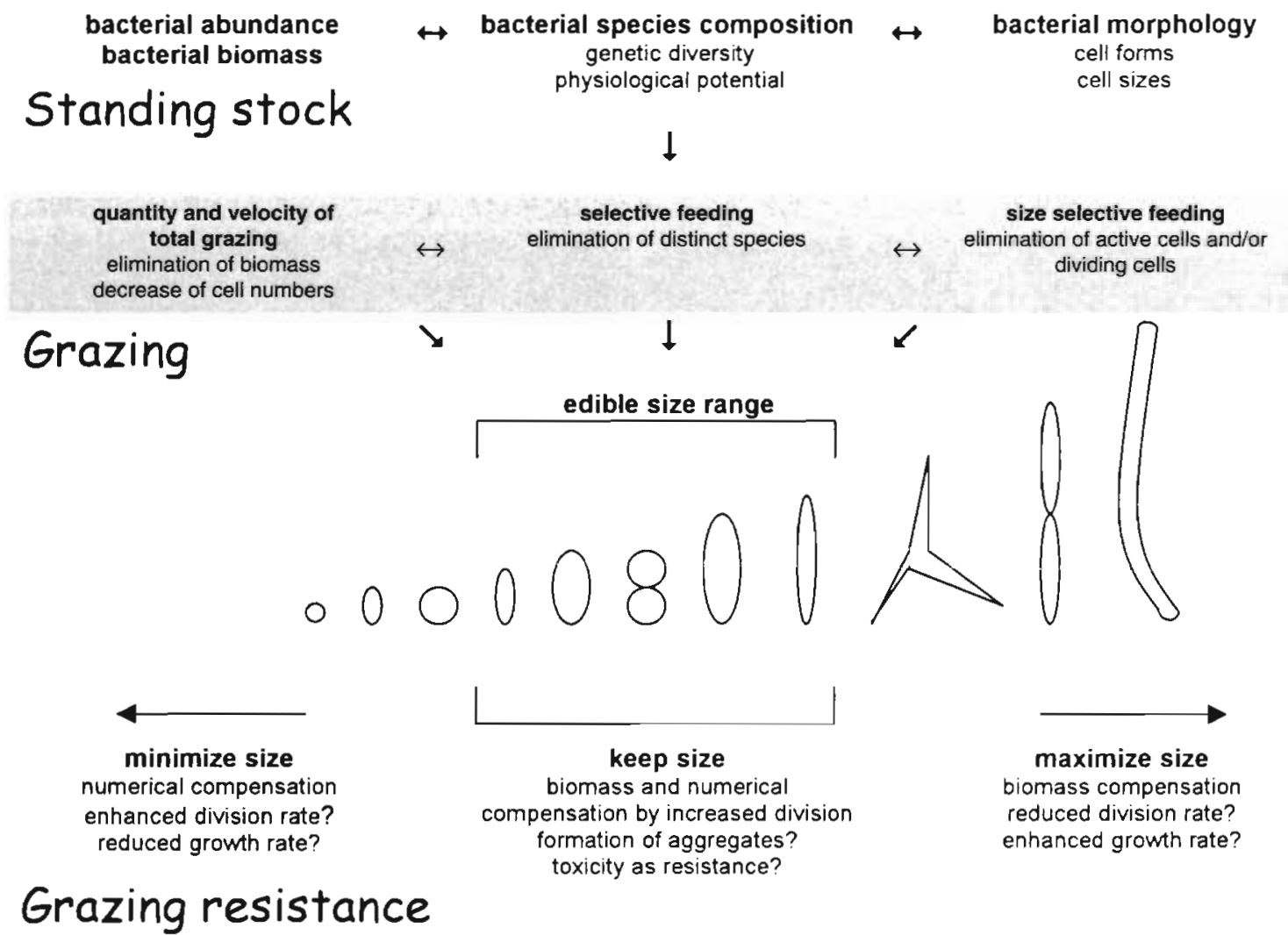

Fig. 7. Possible responses of bacterial communities to protozoan grazing. The impact of grazing pressure can be seen as a combination of several factors (e.g. selective feeding, amount and velocity of total grazing). The reactions on protozoan grazing should be linked with the species composition and/or bottom-up effects

they may fully compensate for grazing losses (Šimek et al. 1997). Filamentation of Comamonas acidovorans and other bacteria has been observed as a consequence of increased growth rate related to grazing pressure (Hahn \& Höfle 1998, M. Hahn pers. comm.). In contrast to an earlier experiment in a comparable set-up (Simek et al. 1997), the formation of filamentous morphotypes as a consequence of predation was not found during the present study (Fig. 4). This is a clear indication that this particular response to grazing depends on the presence or absence of species which have the genetic potential to change their morphology accordingly (Hahn \& Höfle 1998).

However, it is still open to discussion if observed changes in the $\mathrm{BC}$ are an 'active' response to the presence of a predator. Chemical stimuli released by protozoan predators might induce shifts in the bacterial growth patterns and consequently in their size distribution or morphology. Such phenomena have been described for ciliate interspecific relationships (Kuhlmann \& Heckmann 1985, Kusch \& Kuhlmann 1994), and chemical cross talk between bacteria and eukaryotes has been observed before. Alternatively we may only observe 'passive' responses as a reaction on shifts in the competition within the BC (Hahn \& Höfle 1998).

In summary we should consider planktonic protozoa not only as the eliminators of the 'active' fraction of bacterial communities, but also as the driving force of changes in bacterial growth and division patterns, and as agents influencing interspecific competition. These shifts caused by top-down effects may occur at short time scales and can be closely related to limiting bottom-up effects (Psenner \& Sommaruga 1992). Last but not least, the individual changes in bacterial cell size, species composition and production will give feedback on the presence and the wellbeing of their protistan predators. This aspect should be considered in a series of experiments which allow the study of feedback effects of prey consumption on predators. We hope, thus, that our work will draw more attention to the characteristic growth and feeding patterns of individual protistan predators and their conspicuous implications for bacterial communities.

Acknowledgements. We want to thank $\mathrm{R}$. Sommaruga and $\mathrm{S}$. Klammer for their critical and helpful comments on the manuscript. We also thank $H$. Müller and M. Hahn for providing the protozoan cultures. Especially we thank Stefan Andreatta 
for intensive discussion about the experimental set-up. T.P. was financed by a grant from the project 'Effects of different protozoan species on the diversity, morphology and activity of bacterial communities' (OENB 6513) sponsored by the Austrian National Bank. The study was also supported by AKTION Österreich-Tschechische Republik (Wissenschaftsund Erziehungskooperation), Project $17 p 9$ to K.S. and R.P.

\section{LITERATURE CITED}

Andersson A, Larsson U, Hagström A (1986) Size-selective grazing by a microflagellate on pelagic bacteria. Mar Ecol Prog Ser 33:51-57

Berninger UG, Caron DA, Sanders RW, Finlay BJ (1991) Heterotrophic flagellates of planktonic communities, their characteristics and methods to study. In: Patterson DJ, Larsen J (eds) The biology of free-living heterotrophic flagellates. Clarendon Press, Oxford, p 39-56

Bianchi M (1989) Unusual bloom of star-like prosthecate bacteria and filaments as a consequence of grazing pressure. Microb Ecol 17:137-141

Billen G, Servais P, Becquevort S (1990) Dynamics of bacterioplankton in oligotrophic and eutrophic aquatic environments: bottom-up or top-down control? Hydrobiologia $207: 37-42$

Bird DF, Kalff J (1993) Protozoan grazing and the size-activity structure of limnetic bacterial communities. Can J Fish Aquat Sci 50:370-380

Caron DA, Goldman JC, Dennett MR (1988) Experimental demonstration of the roles of bacteria and bacterivorous protozoa in plankton nutrient cycles. Hydrobiologia 159 $27-40$

Chrzanowski TH, Simek K (1990) Prey-size selection by freshwater flagellated protozoa. Limnol Oceanogr 35: $1429-1436$

Fenchel T (1980a) Suspension feeding in ciliated protozoa: functional response and particle size selection. Microb Ecol 6:1-11

Fenchel T (1980b) Suspension feeding in ciliated protozoa: feeding rates and their ecological significance. Microb Ecol 6:13-25

Gasol JM, del Giorgio PA, Massana R, Duarte CM (1995) Active versus inactive bacteria: size-dependence in a coastal marine plankton community. Mar Ecol Prog Ser 128:91-97

Gonzalez JM, Sherr EB, Sherr BF (1990) Size-selective grazing on bacteria by natural assemblages of estuarine flagellates and ciliates. Appl Environ Microbiol 56:583-589

Güde $H$ (1979) Grazing by protozoa as selection factor for activated sludge bacteria. Microb Ecol 5:225-237

Güde $H$ (1989) The role of grazing on bacteria in plankton succession. In: Sommer U (ed) Plankton ecology. Successions in plankton communities. Springer, Berlin, $p$ $357-364$

Guillard RRL, Lorenzen CJ (1972) Yellow-green algae with chlorophyllidae c. J Phycol 8:10-14

Hahn MW, Höfle MG (1998) Grazing pressure by a bacterivorous flagellate reverses the relative abundance of Comamonas acidovorans PX54 and Vibrio strain CB5 in chemostat cocultures. Appl Environ Microbiol 64:1910-1918

Hicks RE, Amann RI, Stahl DA (1992) Dual staining of natural bacterioplankton with 4',6-diamidino-2-phenylindole and fluorescent oligonucleotide probes targeting kingdomlevel 16S rRNA sequences. Appl Environ Microbiol 58: 2158-2163
Jürgens K, Güde H (1994) The potential importance of grazing-resistant bacteria in planktonic systems. Mar Ecol Prog Ser 112:169-188

Kirchman D, Sigda J, Kapuscinski R, Mitchell R (1982) Statistical analysis of the direct count method for enumerating bacteria. Appl Environ Microbiol 44:376-382

Kuhlmann HW, Heckmann K (1985) Interspecific morphogens regulating prey-predator relationships in protozoa. Science 227:1347-1349

Kusch J, Kuhlmann HW (1994) Cost of Stenostomum-induced morphological defence in the ciliate Euplotes octocarinatus. Arch Hydrobiol 130:257-267

Massana R, Gasol JM, Bjørnsen PK, Blackburn N, Hagström $\AA$, Hietanen S, Hygum BH, Kuparinen J, Pedrós-Alió C (1997) Measurement of bacterial size via image analysis of epifluorescence preparations: description of an inexpensive system and solutions to some of the most common problems. Sci Mar 61:397-407

Pernthaler J, Posch T, Simek K, Vrba J, Amann R, Psenner R (1997a) Contrasting bacterial strategies to coexist with a flagellate predator in an experimental microbial assemblage. Appl Environ Microbiol 63:596-601

Pernthaler J, Alfreider A, Posch T, Andreatta S, Psenner R (1997b) In situ classification and image cytometry of pelagic bacteria from a high mountain lake (Gossenköllesee, Austria). Appl Environ Microbiol 63:4778-4783

Porter KG (1988) Phagotrophic phytoflagellates in microbial food webs. Hydrobiologia 159:89-97

Posch T, Pernthaler J, Alfreider A, Psenner R (1997) Cell specific respiratory activity of aquatic bacteria studied with the tetrazolium reduction method, Cyto-Clear slides, and image analysis. Appl Environ Microbiol 63:867-873

Psenner R, Sommaruga R (1992) Are rapid changes in bacterial biomass caused by shifts from top-down to bottom-up control? Limnol Oceanogr 37:1092-1100

Riemann B, Havskum H, Thingstad F, Bernard C (1995) The role of mixotrophy in pelagic environments. In: Joint I (ed) Molecular ecology of aquatic microbes. NATO ASI Series 38. Springer Verlag, Berlin, p 88-114

Rothhaupt KO (1992) Stimulation of phosphorus-limited phytoplankton by bacterivorous flagellates in laboratory experiments. Limnol Oceanogr 37:750-759

Rothhaupt KO (1996) Laboratory experiments with a mixotrophic chrysophyte and obligately phagotrophic and phototrophic competitors. Ecology 77:716-724

Sanders RW (1988) Feeding by Cyclidium sp. (Ciliophora, Scuticociliatida) on particles of different sizes and surface properties. Bull Mar Sci 43:446-457

Sherr BF, Sherr EB, Fallon RD (1987) Use of monodispersed, fluorescently labeled bacteria to estimate in situ protozoan bacterivory. Appl Environ Microbiol 53:958-965

Sherr BF, Sherr EB, McDaniel J (1992) Effect of protistan grazing on the frequency of dividing cells in bacterioplankton assemblages. Appl Environ Microbiol 58:2381-2385

Shikano S, Luckinbill LS, Kurihara Y (1990) Changes of traits in a bacterial population associated with protozoan predation. Microb Ecol 20:75-84

Sieracki ME, Johnson PW, Sieburth JMcN (1985) Detection, enumeration, and sizing of planktonic bacteria by imageanalyzed epifluorescence microscopy. Appl Environ Microbiol 49:799-810

Simek K, Fuksa JK (1989) Responses in bacterial activity to changing conditions in plankton-probable controlling mechanisms. Arch Hydrobiol Beih Ergebn Limnol 33: $239-248$

Šmek K, Vrba J, Hartman P (1994) Size-selective feeding by Cyclidium sp. on bacterioplankton and various sizes of 
cultured bacteria. FEMS Microbiol Ecol 14:157-168

Simek K, Bobková J, Macek M, Nedoma J, Psenner R (1995) Ciliate grazing on picoplankton in a eutrophic reservoir during the summer phytoplankton maximum: a study at the species and community level. Limnol Oceanogr 40 : $1077-1090$

Simek K, Vrba J, Pernthaler J, Posch T, Hartman P, Nedoma J, Psenner R (1997) Morphological and compositional shifts in an experimental bacterial community influenced by protists with contrasting feeding modes. Appl Environ Microbiol 63: $587-595$

Editorial responsibility: John Dolan, Villefranche-sur-Mer, France
Simon M (1990) Improved assessment of bacterial production combined measurements of protein synthesis via leucine and cell multiplication via thymidine incorporation? Arch Hydrobiol Beih Ergebn Limnol 34:151-155

Sommaruga R, Psenner R (1995) Permanent presence of grazing-resistant bacteria in a hypertrophic lake. Appl Environ Microbiol 61:3457-3459

Zimmermann R, Iturriaga R, Becker-Birck J (1978) Simultaneous determination of the total number of aquatic bacteria and the number thereof involved in respiration. Appl Environ Microbiol 36:926-935

Submitted: November 16, 1998; Accepted: February 10, 1999 Proofs received from author(s): July 23, 1999 